Indonesian Journal of EFL and Linguistics

Vol. 2 No. 1, 2017

eISSN: 2503-4197, pISSN: 2527-5070

www. indonesian-efl-journal.org

\title{
An Examination of the Impact of Computer Skills on the Effective Use of ICT in the Classroom
}

\author{
Az-eddine Khaloufi \\ Moulay Ismail University, Meknés, Morocco \\ Hicham Laabidi \\ Sidi Mohamed Ben Abdellah University, Fes, Morocco \\ e-mail:Hicham.laabidi@yahoo.com
}

\begin{abstract}
:
The purpose of this paper is to examine the effect of computer skills on the successful integration of Information and Communication Technologies (ICTs) in Moroccan higher education institutions. Actually, the survival of these institutions in the expansion of modern technologies depends on their readiness to qualify professors and students to implement ICTs for educational objectives. Because of the significant role that computer technologies play in today's job markets, higher education institutions are required to provide the most appropriate learning and teaching conditions for both professors and students to make effective use of these new technologies within classroom practices. The findings revealed that teachers consider ICTs very essential in their teaching. However, there are low levels of computer technology integration in teaching processes. This lack of computer technology use in instruction is attributed to several factors. One of these various factors is teachers' computer skills. It has been found that there are statistically significant differences between professors' use of ICT with respect to their computer skills, $F(4,158)=32.776, p<0.05$.
\end{abstract}

Keywords : computer skills, Information and Communication Technologies, higher education institutions, classroom practices 


\section{INTRODUCTION}

It is apparent that computer technology has become an important part of our daily lives. "Whether or not we touch a computer, it is almost impossible to escape its daily influence on us; from speedy information transmittal, printouts, and receipts, to control of lights and temperature of our workplaces" (Deaton, 1990,p.1). If schools and universities tend to prepare learners for today's job market, they should encourage the integration of computer technologies into the curriculum (Soine, 1996). If these educational institutions are not utilizing ICT, they are neglecting a significant portion of their learners' environment (Cummings, 1998). In fact ,“ convergence of the economic necessities called into question the effectiveness of the educational system to prepare the future workforce with adequate amounts of human capital ( knowledge, skills, and dispositions) to compete in world markets and economies" (Hornbeck \& Salamon, 1991,p.65)

Therefore; teachers, in this information technological age, should know both the subject matter they instruct and the different effective ways this subject matter may be changed using computer technologies (Misha \& Koehler, 2006). They are required to develop sufficient knowledge about technologies such as computers, the Internet and digital videos. This knowledge should incorporate how to install and remove several significant software programmes. In other words, they are required to master the necessary skills to operate different software tools especially word processors, Internet browsers, spreadsheets, and email (Mishra \& Koehler, 2006). This is due to the fact that there has been a shift from a focus on information transmission through books and chalk to a concentration on information processing via computers and the internet (Barker, 1994).

Numerous studies have indicated that there is a strong positive correlation between students' achievements and the use of ICT in the classroom. Schacter (1999) carried out a meta-analysis of more than 700 research studies done within the state of West Virginia with samples of learners who had access to several kinds of technologies in their learning. He claimed that the targeted students showed "positive gains in achievement on research constructed tests, standard tests, and national tests" (p.9). Schacter's feedback reinforced the necessity for instructors to include technology into the educational environment. Similarly, Waxman, Connell, and Gray (2002) conducted a research study which reviewed both quantitative and quasi-experimental research publications from 1997 to 2002 related to the influence of computer technology on learners' achievement. They found that the implementation of ICT within classroom practices has positive effects on students' learning.

Prensky (2001) stated that technology has changed education especially the learner. The student of the 21 st century has directly been affected since " they are used to the instantaneity of hypertext, download music, phones in their pockets, a library on their laptops, beamed messages and instant messaging" (Presnsky, 2001, p.4). According to Matusevich (1995), technology has restructured the whole process of learning and teaching in the sense that it has helped students to reshape their learning strategies. 
Bull (2005) stated that computer technology integration could help learners develop their thinking skills and creative abilities in the sense that they have access to more technological tools outside of educational institutions than inside schools. This shift "is largely occurring outside of schools, however with little integration in the curriculum within school walls. Despite progress, use of these technologies by students within schools remains limited, largely confined to visits to school laboratories on special occasions" (Bull, 2005, p.11). Actually, there is an increasing tendency among students to make use of several different technological devices to generate content (Lenhart, Simpson and Graziano, 2001). So, educators cannot overlook the imperative necessity to integrate these technologies within their classrooms (Bates, 2006; Chamblis, 2003; Fox, 2007; Obler \& Schiorring, 2002; Falmer, 2012; Thang, et al., 2016; Ganapathy, et al., 2017).

\section{LITERATURE REVIEW}

Firstly, it is must be admitted that there is little agreement among researchers on an exact definition of computer experience (Thompson et al., 2006). Thompson et al. (2006) stated that computer experience refers to the habit of making use of technological instruments and the development of "the skills and abilities that one gains through using a technology" (p.43). Individuals' experience with computers can be measured based on some important criteria such as ownership of a computer, type of computer training, years of use and the frequency of utilizing computer technology (Potosky \& Bobko, 1998). In this context, it is vital to note that Marquie, Thon \& Baracat (1994) conducted a study to investigate the relationship between computer attitudes, computer experience and the quality of computer training they received. The researchers revealed that the most influential variable that has a great impact on attitudes was computer experience. So, teachers' use of computer technology in their teaching may be affected by the level and the kind of experience with computers they have received (Woods et al., 2004; Christensen, 2002).

Despite the accessibility of computer technologies in various educational institutions, many college professors are hesitant to integrate ICT and modify their way of teaching (Dusick, 1998; Hunt \& Bohlin, 1995; Yildirim, 2000) and the teachers of English do not integrate ICT tools on a regular basis due to the existence of several barriers related to teachers as well as the institutions (Laabidi \& Laabidi, 2016; Chouit, et al., 2017). Several other teachers, on the other hand, expand efforts in order to ameliorate their knowledge and experience in the use of educational technologies (Bai-Chuvessiriporn \& Lehmam, 2001). High levels of computer experience improve individuals' perceptions of computer competency and computer importance (Czaja \& Sharit ,1998). The level of computer experience has a great influence over attitudes regarding the use of computer technology (Koohang \& Byrd, 1987). In fact, the amount of computer experience is thought to have a great influence over teachers' attitudes regarding the use of computer technology for instructional purposes (Koohang \& Byrd, 1987) .

Professors with earlier exposure to computer technologies normally demonstrate more concern in using ICT across the curriculum (Bradley \& Russell, 1997). However, professors who do not have any previous computer experience are 
reported to be reluctant because of different factors namely inadequate experience and knowledge (Kay, 1999). In other words, teachers who lack the necessary computer background and competence are likely to be hesitant to integrate ICT in their teaching (O'Quinn and Corry, 2002). Thus, insufficient contact with modern technological devices and lack of computer skills usually result in limited confidence in trying to integrate ICT across the curriculum (Oppenheimer, 1999).

The kind of teachers' computer utilizations is dependent on both their knowledge and attitudes towards implementing these technologies in their instruction (Davidson, 1989). If they accept to adopt ICT in classroom practices and have enough knowledge of how computer technology is successfully integrated, teachers will undoubtedly help their students learn better through the use of these tools (Christensen, 2002). Therefore, the relationship between teachers' attitudes and their knowledge is interconnected in the sense that each one influences the other. Attitudes and knowledge about computers might have a great effect on instructors' use of ICT in teaching. This simply means that teachers who possess sufficient knowledge about computer integration in teaching practices are expected to develop positive attitudes towards computers. Poor knowledge regarding how to better integrate ICT into the curriculum, on the other hand, might lead to an unfavourable behaviour toward computers (Christensen, 2002; Davidson, 1989).

Various research studies displayed the existence of a strong positive correlation between professors' previous computer experiences and their attitudes regarding the implementation of ICT in education .For example, DuPagne \& Krendl (1992) found that there is a significant positive correlation between teachers' computer experience and their attitudes regarding the use of ICT for instructional purposes. They concluded that teachers' eagerness rises as their exposure to computer technology grows. Similarly, Dusick and Yildirim (1998) revealed that there is a strong relationship between teachers' previous contact with computers and their attitudes toward using them in the teaching process. Numerous studies have found that computer experience reduces the fear of utilizing ICT for teaching goals (Dyck \& Smither, 1994; Lee, 1997).

Panda and Misha (2007) conducted a study to examine the attitudes of 150 faculty members toward the use of educational technology. The results showed a strong significant correlation between attitudes and professors' computer skills. Accordingly, Kagima \& Hausafus (2000) investigated the confidence of 176 professors at the University of Iowa State regarding the integration of educational technologies. The findings revealed that instructors who have developed satisfactory competence and experience in making use of computer technology possess positive attitudes and are inclined to use other different technological tools. In the same framework, Vakalis (1991) conducted an identical investigation in the state of Michigan. He found that professors who incorporate ICT in their classroom practices show more confidence and computer liking, have higher levels of precious exposure to computers and face less apprehension towards the use of ICT in their teaching. These results assert that previous experience with computer technology is 
a key factor that helps teachers develop favourable attitudes regarding the integration of ICT in teaching process.

Bradley and Russell (1997) carried out a research study to examine the role of experience on the growth of computer skills and attitudes. The distinction between their investigation and the former ones lies in the fact that they established a difference between quantity and quality of previous experiences. They emphasized that the better the quality of the training, the more favourable attitudes teachers develop regarding the adoption of ICT in the classroom. Besides, Levy (2003) conducted a survey to examine the different factors that should be taken into account when universities intend to encourage professors to adopt computer technology in the classrooms. The findings indicated that

Due to the current lack of adequate support at most institutions of higher education, online distance learning instructors must have adequate technology skills. They often need to upload their own files, deal with hardware and software problems, and help students overcome their own problems with the technology. Instructors must be able to design their courses, making sure they are accessible to disabled students. (p.4)

Computer experience has been considered as one of the most influential factors affecting computer usage (Glass \& Knight, 1998; Laabidi, 2016). Greater levels of computer experience means less computer anxiety and higher positive attitudes toward the use of computer technologies (Howard \& Smith, 1986). According to Glass \& Knight (1998), computer experience is a significant predictor of computer anxiety. Also, they revealed that adequate computer experience means lack of computer anxiety and higher levels of positive attitudes toward computers. When teachers receive enough experience working with computers, their computer anxiety decreases (Anderson \& Reed, 1998). Yang, Mohamed and Beyerbach (1999) undertook their investigation to account for how computer experience influences the connection of teachers' computer anxiety and their characteristics namely age, gender, subject area, kind of institution and educational level. They concluded that most of participants who were engaged in computer-based training have favourable attitudes regarding the integration of computer technologies in classroom activities. Also, Yang et al. found that computer experience affects computer anxiety which is connected with the teachers' characteristics of age and subject taught.

Bradley \& Russell (1997) proclaimed that the most influential factor regarding attitudes toward computer technology is the quality rather than the quantity of previous computer experiences. In their study of office workers regarding computer attitudes, computer experience and the level of training, Marquie, Thon, \& Baracat (1994) reported that computer experience is the most significant factor that affects their attitudes toward computers. Also, they found that computer users who are highly experienced believe that computers are more useful and more valuable than those users who possess less computer experience. Rogers (2000) mentioned that having the required computer skills represent a vital factor which influences professors' choice of whether or not to integrate computer technology in their teaching. Therefore, faculty members are required to develop appropriate 
technological skills to be able to use the various kinds of technological instruments so that effective teaching can take place (Valentine, 2002) .

Finally, most studies on professors' attitudes regarding the use of educational technology have focused on computer-related skills, knowledge, experience, and training. These studies stressed that university teachers must develop satisfactory knowledge and sufficient skills to feel comfortable with computer technology as a pedagogical instrument employed to promote teaching and learning (Bates et al., 2001). Generally, more experience with computer technologies will result in the development of more favourable attitudes toward the use of ICT (Jay \& Willis, 1992; Krauss \& Hoyer, 1984). However, the possession of less computer experience or negative attitudes toward the use of ICT is expected to result in teachers' reluctance to integrate these new technologies in their teaching practices (Poole \& Jackson, 1993). Enough experience with computer technology plays an important part in ICT adoption among teachers (Taylor \& Todd, 1995; Thompson et al., 2006; Venkatesh et al., 2003). Woods et al. (2004) conducted a study including 862 teachers from 38 universities to examine how teachers' experience with computer technology can influence their adoption of ICT for instructional purposes. The researchers concluded that experience with the use of computer technology played a significant part in whether or not teachers are likely to integrate ICT in their teaching. Actually, insufficient computer experience is expected to increase teachers' anxiety of integrating computer technology across the curriculum (Sigurdsson, 1991).

\section{RESEARCH METHODOLOGY}

In this study, approximately 300 teachers were summoned to take part. However, only $195(65 \%)$ full-time and part-time English teachers agreed to respond to the survey. The researchers discarded 32 questionnaires which were incomplete since they had significant parts of the survey instrument missing. Hence, 163 (54, 33\%) answered the questionnaire appropriately. Finally, the resulting sample size employed in this study was a total of 163 teachers working in various Moroccan higher institutions.

Both descriptive and inferential statistical analyses were used to answer the research question: are there any significant differences in professors' use of ICT according to their computer skills? Descriptive statistics were employed to analyze the demographic data. However, inferential statistics, mainly the one-way ANOVA was utilized to account for the differences between professors based on computer skills. The dependent variable was professors' use of computer technology and the independent variable was the level teachers' computer skills.

\section{FINDINGS}

\subsection{Demographic Data of the Participants}

Responses on the first section of the survey questionnaire provided demographic data about the professors who participated in this study. The data describing the demographic characteristics were computed and analyzed using descriptive statistics 
such as frequencies and percentages. The examined demographic information incorporated age, university of affiliation and computer skills.

\subsubsection{Age of the Participants}

As shown in figure 1, the age of the participants in this study ranged from less than 30 to greater than 51. About half of the participants $(46.6 \%, \mathrm{n}=76)$ were 51 years old or older. Also, almost one third of the respondents $(28.2 \% ; \mathrm{n}=46)$ were within the $41-50$ age range, $16.6 \%(\mathrm{n}=27)$ were between $30-40$ age range, and only $8.6 \%$ $(\mathrm{n}=14)$ were less than 30 years old.

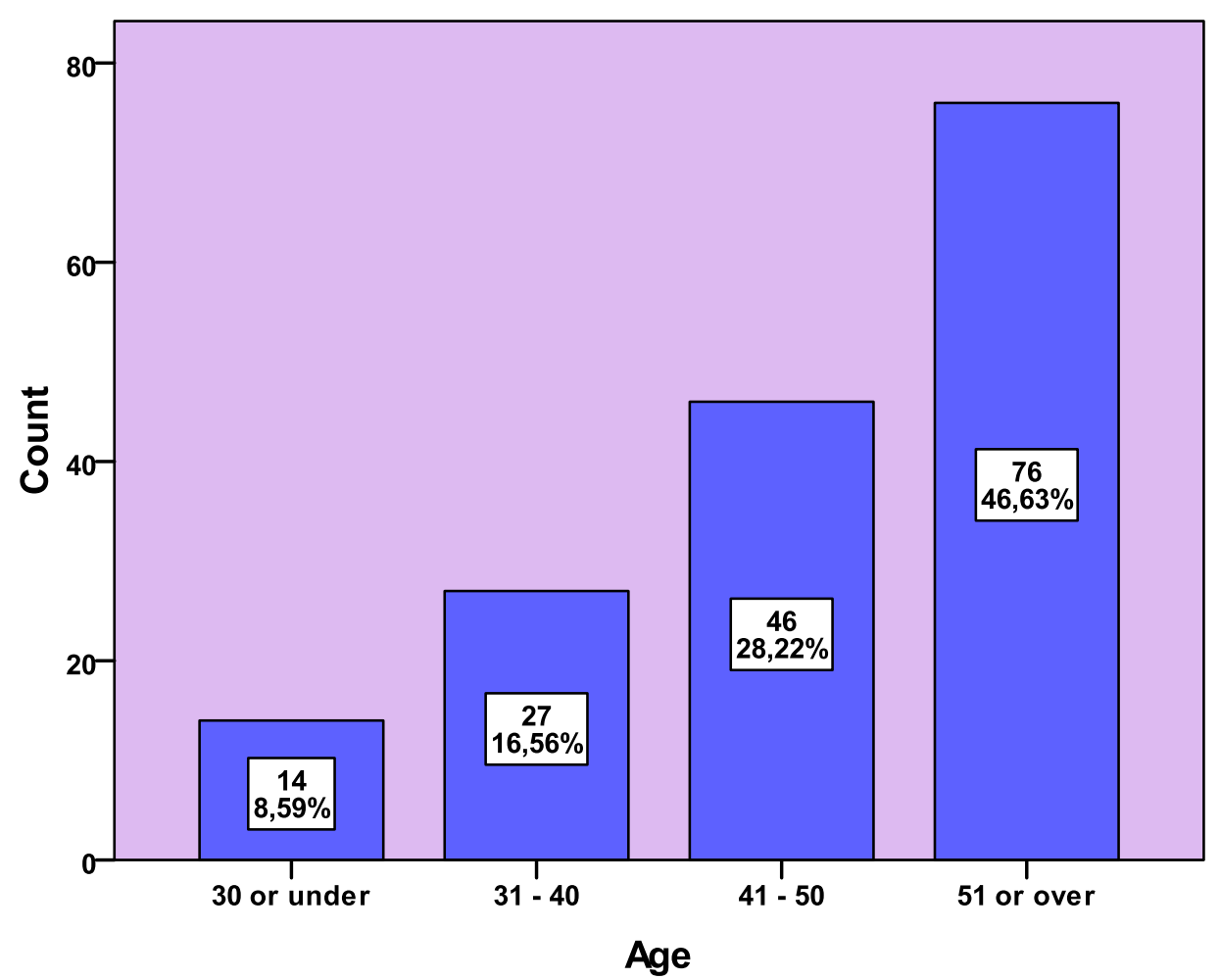

Figure 1. Distribution of Participants by Age

\subsubsection{University of Affiliation of the Participants}

As illustrated in Figure 2, the professors participating in this study were from thirteen different Moroccan universities. The highest percentage of the respondents $21.5 \%(\mathrm{n}=35)$ taught English language at Moulay Ismail University followed by Sidi Mohammed BenAbdellah university, $14.1 \%(\mathrm{n}=23)$. Of the 163 participants, $11.7 \%(\mathrm{n}=19)$ taught at Mohammed V. The data showed that the representation of Mohammed I was somewhat less, $4.3 \%(\mathrm{n}=7)$, equal with both Ibnou Zohr and Soultane Solimane universities. 


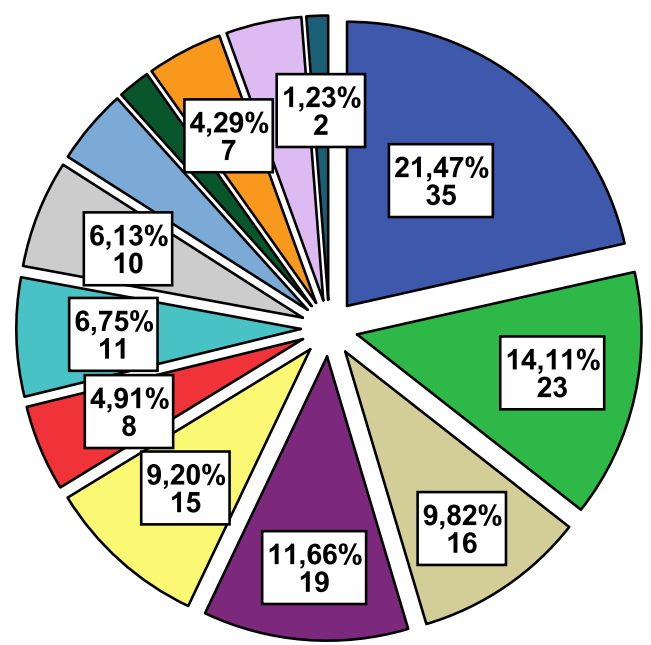

\section{University of affiliation}

$\square$ Moulay Is mail

$\square$ Sidi Mohammed

BenAbde llah

$\square$ Moham med V

$\square$ Hassan II

$\square$ Hassan I

$\square$ Chouaib Doukali

$\square$ Caddi Ayyad

$\square$ Ibnou Zohr

AbdEmalek

Essaadi

$\square$ Moham med I

$\square$ Soultane Solimane

$\square$ Al Akhaw ayne

Figure 2. Distribution of Participants by University of Affiliation

\subsubsection{Computer skills of the Participants}

As shown in Figure3, more than half of the participants $(n=87 ; 53.4 \%)$ reported that possessed an average level regarding the degree of their computer skills. Also, quarter of the respondents $(n=42 ; 25.8 \%)$ stated that they were advanced when using computer technologies. Only nine professors $(5.5 \%)$ announced that their computer skills level was very low.

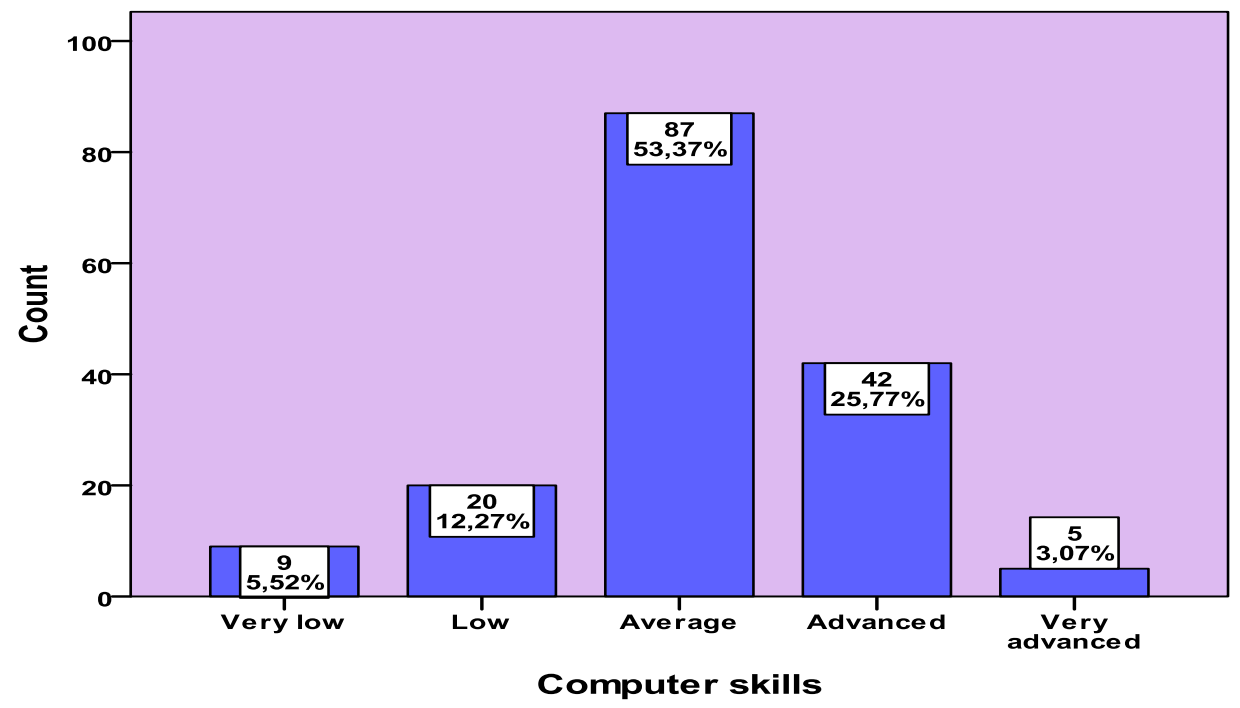

Figure 3. Distribution of Participants by Computer Skills 


\subsection{Findings Related to the Research Questions}

The main purpose of this research question is to investigate professors' differences in the extent to which they integrate ICT based on their computer skills. The Analysis of Variance (ANOVA), especially the one-way ANOVA was employed to compare the mean scores of the five groups in the independent variable The ANOVA analysis was chosen because there are two variables: one continuous dependent variable ( professors' use of ICT in teaching) and one categorical independent variable (professors' computer skills).Actually, the categorical variable has four different classes ( Group1: very low ; Group 2: low; Group3: average ; Group 4: advanced; Group 5: very advanced ). A Scheffé post hoc test was carried out following the ANOVA since significant differences between professors' use of ICT for educational goals was found. In other words, the test was conducted to determine which group was significantly different from other groups. Table 1 shows the descriptive statistics of each computer skills group in terms of ICT integration.

Table.1 Descriptive Statistics of Professors' Computer Skills

\begin{tabular}{|c|c|c|c|c|}
\hline Computer Skills & N & Mean & Std. Deviation & Std. Error \\
\hline Very low & 9 &, 64 &, 85 &, 28 \\
Low & 20 &, 46 &, 23 &, 05 \\
Average & 87 & 1,70 &, 88 &, 09 \\
Advanced & 42 & 2,57 &, 67 &, 10 \\
Very advanced & 5 & 2,71 &, 29 &, 13 \\
Total & 163 & 1,74 & 1,02 &, 08 \\
\hline
\end{tabular}

According to Table 1, the highest mean $(\mathrm{M}=2.71, \mathrm{SD}=0.29)$ was scored by respondents who had very advanced computer skills. The second highest mean $(\mathrm{M}=2.57, \mathrm{SD}=0.67)$ was achieved by professors who were advanced with respect to the use of computers. Also, it is clear from the findings that participants who had average computer skills obtained a mean of $1.70(\mathrm{SD}=0.88)$. In fact, the lowest means were recorded by respondents who had low $(\mathrm{M}=0.46, \mathrm{SD}=0.23)$ or very low computer skills ( $\mathrm{M}=0.64, \mathrm{SD}=0.85$ ). These findings are well-demonstrated in figure 4. 


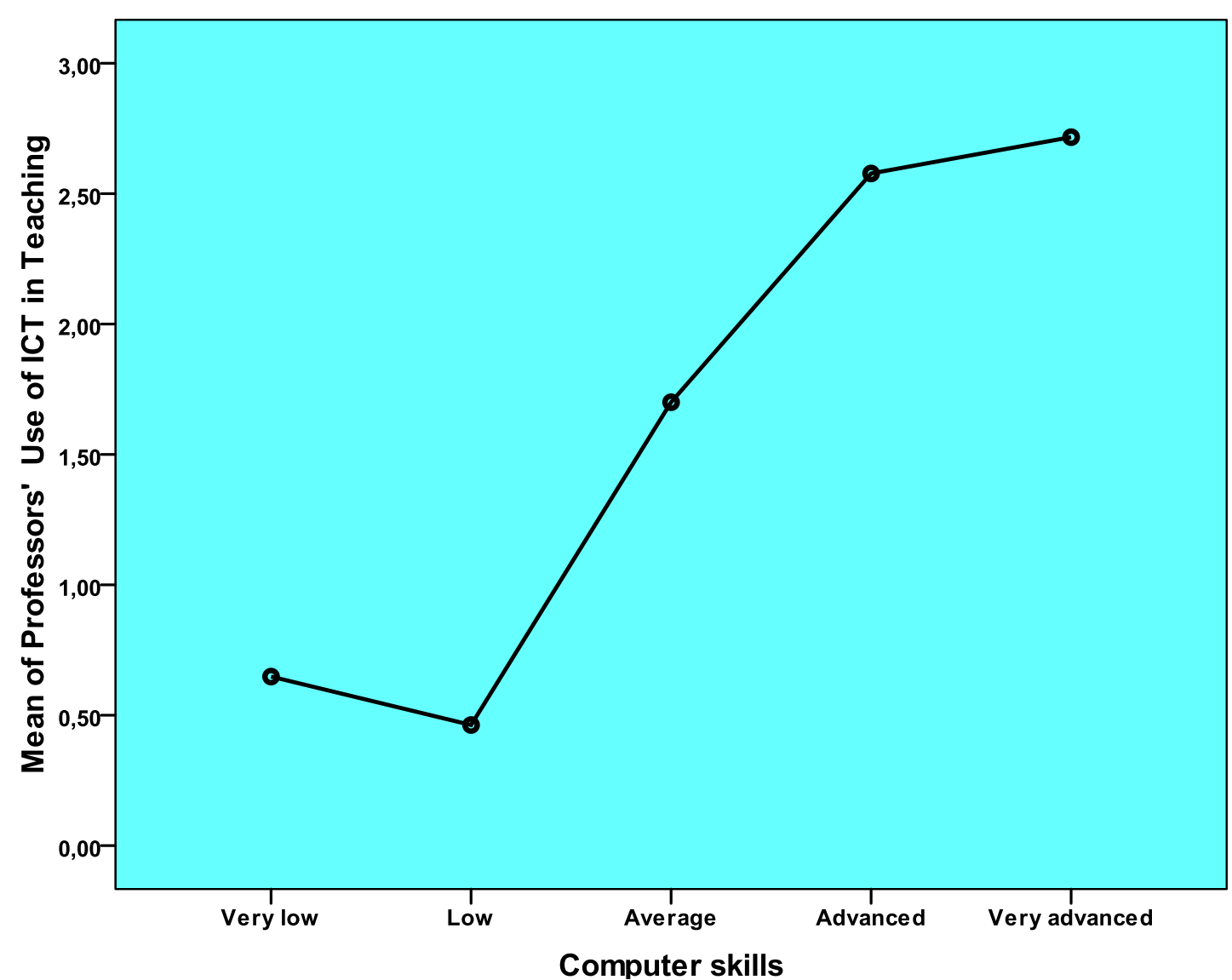

Figure 4. Means Plot for computer skills and ICT use in teaching.

As shown in the means plot above, it can be noted that professors who had advanced or very advanced computer skills are likely to make more use of the new technologies for instructional objectives. Indeed, respondents who had low or very low computer skills do not integrate these technologies frequently in their classrooms.

Table 2 One-way between groups ANOVA for computer skills and ICT use in teaching.

\begin{tabular}{|c|c|c|c|c|c|}
\hline ANOVA & Sum of Squares & Df & Mean Square & F & Sig. \\
\hline Between Groups & 77,718 & 4 & 19,430 & 32,776 &, 000 \\
Within Groups & 93,663 & 158 &, 593 & & \\
Total & 171,381 & 162 & & & \\
\hline
\end{tabular}

It is clear from table 2 that there are statistically significant differences between professors' use of ICT with respect to their computer skills, $F(4,158)=$ $32.776, \mathrm{p}<0.05$.The test found that the $\mathrm{p}$ value $(\mathrm{p}=0.000)$ was smaller than the significant level set at 0.05 (2-tailed). Therefore, the null hypothesis indicating that there were no significant differences between the two variables was rejected. 
However, the alternative hypothesis suggesting that there were significant differences between the two variables was accepted.

The effect size, calculated using eta squared, was 0.45 . To interpret the strength of Eta squared values, the following guidelines were used: $0.01=$ small effect, $0.06=$ moderate effect, 0.14=large effect (Cohen, 1988). The magnitude of the differences in the means was large (eta squared $=0.45$ ). This indicates that $45 \%$ of the variance in professors' use of ICT in the classroom is explained by teachers' computer skills. Actually, the one-way ANOVA test revealed that differences exist among the various computer skills groups. Therefore, a Scheffé Post Hoc test was used to determine which group is significantly different from other groups. The findings are displayed in the following table.

Table.3 Post Hoc Test (Scheffe) for computer skills and ICT use in teaching.

\begin{tabular}{|c|c|c|c|c|c|c|}
\hline \multirow{2}{*}{$\begin{array}{l}\text { (I) Computer } \\
\text { skills }\end{array}$} & \multirow{2}{*}{$\begin{array}{l}\text { (J) Computer } \\
\text { skills }\end{array}$} & \multirow{2}{*}{$\begin{array}{c}\text { Mean } \\
\text { Difference (I-J) }\end{array}$} & \multirow{2}{*}{$\begin{array}{l}\text { Std. } \\
\text { Error }\end{array}$} & \multirow[b]{2}{*}{ Sig. } & \multicolumn{2}{|c|}{ 95\% Confidence Interval } \\
\hline & & & & & Lower Bound & Upper Bound \\
\hline \multirow[t]{4}{*}{ Very low } & Low &, 18565 & ,30904 & ,985 &,- 7776 & 1,1489 \\
\hline & Average & $-1,05204^{*}$ & ,26959 &, 006 & $-1,8924$ &,- 2117 \\
\hline & Advanced & $-1,92923^{*}$ &, 28281 &, 000 & $-2,8107$ & $-1,0477$ \\
\hline & Very advanced & $-2,06852^{*}$ & ,42945 &, 000 & $-3,4071$ &,- 7299 \\
\hline \multirow[t]{4}{*}{ Low } & Very low &,- 18565 & ,30904 & ,985 & $-1,1489$ & ,7776 \\
\hline & Average & $-1,23769^{*}$ & , 19093 &, 000 & $-1,8328$ &,- 6426 \\
\hline & Advanced & $-2,11488^{*}$ & ,20918 &, 000 & $-2,7669$ & $-1,4629$ \\
\hline & Very advanced & $-2,25417^{*}$ & ,38497 &, 000 & $-3,4541$ & $-1,0542$ \\
\hline \multirow[t]{4}{*}{ Average } & Very low & $1,05204^{*}$ & ,26959 &, 006 &, 2117 & 1,8924 \\
\hline & Low & $1,23769^{*}$ & , 19093 &, 000 & ,6426 & 1,8328 \\
\hline & Advanced &,$- 87719^{*}$ & , 14467 &, 000 & $-1,3281$ &,- 4263 \\
\hline & Very advanced & $-1,01648$ & ,35408 &, 089 & $-2,1201$ & ,0872 \\
\hline \multirow[t]{4}{*}{ Advanced } & Very low & $1,92923^{*}$ &, 28281 &, 000 & 1,0477 & 2,8107 \\
\hline & Low & $2,11488^{*}$ & ,20918 &, 000 & 1,4629 & 2,7669 \\
\hline & Average &, $87719^{*}$ & , 14467 &, 000 & ,4263 & 1,3281 \\
\hline & Very advanced &,- 13929 &, 36425 & ,997 & $-1,2746$ & ,9961 \\
\hline \multirow{4}{*}{$\begin{array}{l}\text { Very } \\
\text { advanced }\end{array}$} & Very low & $2,06852^{*}$ & ,42945 &, 000 & ,7299 & 3,4071 \\
\hline & Low & $2,25417^{*}$ & ,38497 &, 000 & 1,0542 & 3,4541 \\
\hline & Average & 1,01648 &, 35408 & ,089 &,- 0872 & 2,1201 \\
\hline & Advanced & ,13929 &, 36425 & ,997 &,- 9961 & 1,2746 \\
\hline
\end{tabular}

Indonesian Journal of EFL and Linguistics, Vol. 2 (1), 2017 
From the results shown above (Table 3 ), it is clear that group 5 (very advanced) is statistically different from group 1 (very low) and group 2 ( low).This difference indicates that respondents who had very advanced computer skills integrate ICT in their teaching more frequently than those who had low or very low computer skills. Indeed, the findings also revealed that very advanced respondents are not statistically different those who had average or advanced computer skills.

\section{DISCUSSION}

The findings showed that professors' computer skill is an important factor in relation with technology integration in teaching. After reviewing the data analysis for the research question, the null hypothesis stating that there were not any differences between teachers' use of ICT based on computer skills was rejected because significance differences were found between the independent and dependent variables, $F(4,158)=32.776, p<0.05$. The results revealed that professors who possessed very advanced computer skills scored the highest mean ( $M=2.71$, $\mathrm{SD}=0.29$ ). However, professors who had low ( $\mathrm{M}=0.46, \mathrm{SD}=0.23$ ) or very low computer skills ( $\mathrm{M}=0.64, \mathrm{SD}=0.85$ ) obtained the lowest means. This means that teachers who are very proficient in using ICT gadgets demonstrated high levels of computer technology implementation than those who have less computer competency. The more computer proficiency teachers possess, the higher their levels of ICT integration. Based on these findings, it can be concluded that the factor of computer skills appears to influence professors' use of computer technology in the classrooms.

These results support the findings of Wozney et al. (2006) who found that there was a significant positive correlation between computer proficiency and the actual integration of ICT for pedagogical purposes, meaning that as computer competency rises, the levels of computer technology increase as well. Furthermore, Woodrow (1992) concluded that college professors with high levels of computer skills tend to show greater interest in utilizing the new innovative technologies into their curriculum. Similar findings were reported by Yildirim (2000) who conducted a study including 117 faculty members at California community colleges. The researcher found that the more computer skills faculty members have, the more confident they are with computers, and the more they are expected to integrate ICT in teaching and learning processes.

\section{CONCLUSION}

Moroccan university English language teachers view information and communication technology tools as very essential in their teaching practices. Actually, teachers are aware of the importance of utilizing computer technologies for pedagogical purposes. However, it was found that there are several barriers that impede the successful adoption of ICTs in the classroom. In fact, universities must go beyond the policy of providing more sophisticated technological equipments in the classrooms. Instead, the designers of professional development plans are required to provide programs that would help professors acquire suitable technological skills and thus enhance students' achievements. When employed 
appropriately by skilled professors, these technological instruments can increase learning opportunities for all students and become powerful tools in supporting their achievements.

\section{REFERENCES}

Anderson, D., \& Reed, W.(1998). The effects of Internet instruction, prior computer experience, and learning style on teachers' Internet attitudes and knowledge. Journal Educational Computing Research, 19(3), 227-246.

Bai, H., Chuvessiriporn, S., \& Lehman, J.(2001). Impact of P3T3 on faculty use of Web course tool .From http://p3t3.soe.purdue.edu/WebTool.pdf.

Barker, F. (1994). Integrating computer usage in the classroom curriculum through teacher training. (ERIC Document Reproduction Service No. ED 372 751)

Bates, A. W. (2006). Managing technological change: Strategies for college and university leaders. Retrieved June $17^{\text {th }}, 2015$ from http://media.wiley.com

Bates, T., \& Epper, R.M. (2001). Teaching faculty how to use technology: Best practice from leading institutions. The American Council on Education and The Oryx Press. Jossey-Bass Inc., Publishers, 350 Sansome Street, San Francisco, California 94104.

Bradley, G., \& Russell, G. (1997). Computer experience, school support, and computer anxiety. Educational Psychology, 17(3), 267-284.

Bull, G. (2005). Children, computers, and powerful ideas. Contemporary Issues in Technology and Teacher Education, 5, (3/4).

Chamblis, C. (2003). Managing academic departments: Protecting productivity in the face of staffing and technology changes. Retrieved from ERIC.

Christensen, R. (2002). Effects of technology integration education on the attitudes of teachers and students. Journal of Research on Technology in Education, 34(4), 411-433.

Chouit, D., Nfissi, A., Laabidi, H. (2017). Exploring the Correlation between Professors' Use of ICT in Teaching and the Levels of Institutional Support. JELTL (Journal of English Language Teaching and Linguistics), 2(1), 2017. doi: http://dx.doi.org/10.21462/jeltl.v2i1.39

Cohen, J. (1988). Statistical power analysis for the behavioral sciences. Hillsdale, NJ: Erlbaum.

Cumminngs, C. A. (1998). Teacher attitudes and effective computer integration. (ERIC Document Reproduction Services No. ED 419 512).

Czaja, S. J., \& Sharit, J. (1998). Age differences in attitudes toward computers. Journal of Gerontology, 53B, 329-340.

Davidson, J. ( 1989). Children and computers together in the early childhood classroom. Albany, NY : Delmar Publishers.

Deaton, M. P. (1990). Computer integration in the primary grades. (ERIC Document Reproduction Services No. ED 337 137).

DuPagne, M., \& Krendl, K.A. ( 1992). Teachers' attitudes toward computers : A review of the literature. Journal of Research on Computing in Education, 24, 420-429. 
Dusick, D. M., \& Yildirim, S. (2000). Faculty computer use and training: Identifying distinct needs for different populations. Community College Review, 27(4), 33-45.

Dusick, D.M. ( 1998). What social factors influence faculty members' use of computers for teaching? A literature review. Journal of Research on Computing Education, 3(20), 123-137.

Dyck, J. L., \& Smither, J. A. (1994). Age differences in computer anxiety: The role of computer experience, gender, and education. Journal of Educational Computing Research, 10, 239-247.

Falmer, Roger. (2012). A Third Way: Online Labs Integrated With Print Materials. Indonesian Journal of Applied Linguistics, 2(1), 2012. DOI: http://dx.doi.org/10.17509/ijal.v2i1.660

Fox, B. (2007). Teaching through technology: Changing practices in two universities. International Journal on E-learning, 6 (2), 187-203.

Ganapathy, M., et al. (2017). Promoting Higher Order Thinking Skills via Teaching Practices. 3L: Language, Linguistics, Literature ${ }^{\circledR}, 23(1), 2017$. DOI: http://doi.org/10.17576/3L-2017-2301-06

Glass, C., \& Luanne, K.(1998). Cognitive Factors in Computer Anxiety. Cognitive Therapy and Research, 12, 351-366.

Hornbeck, David A. \& Salamon, Lester M. (1991). Human capital andamerica's future. Baltimore, MA: Johns Hopkins University Press.

Hunt, N.P., \& Bohlin, R.M. ( 1995). Events and practices that promote positive attitudes and emotions in computing courses. Journal of Research on Computing in Teacher Education, 11(3), 21-23.

Jay, G., \& Willis, S. (1992). Influence of direct computer experience on older adults attitudes toward computers. Journal of Gerontology: Psychological Science, 47, 250-257.

Kagima, L. K. \& Hausafus, O. (2000). Integration of electronic communication in higher education: contributions of faculty computer self-efficacy. The internet and Higher Education, 2(4), 221-235.

Kay, R. (1999). Understanding gender differences in computer attitudes, aptitude and use: An innovation to computers. The computer Attitude Measure (CAM), Computer in Human Behavior, 9, 31-386.

Koohang, A., \& Byrd, D. (1987). A study of selected variables and further study. Library and Information Science Research, 9(1), 105-111.

Krauss, I., \& Hoyer, W. ( 1984). Technology and the older person: Age, sex, and experience as moderators of attitudes towards computers. New York: Plenum Press.

Laabidi, Hicham. (2016). The Effect of Age on English Professors' Integration of the New Technologies in Teaching. IJELTAL (Indonesian Journal of English Language Teaching and Applied Linguistics), 1(1), 2016

Laabidi, Youssouf \& Laabidi, Hicham. (2016). Barriers Affecting Successful Integration of ICT in Moroccan Universities. JELTL (Journal of English Language Teaching and Linguistics), 1(3), 2016 
Lee, D. (1997). Factors influencing the cuss of computer skill learning among inservice teachers. British Journal of Educational Technology, 28, 139-141.

Lenhart, H., Simpson, M., \& Graziano, M. (2001). The Internet and Education: Findings of the Pew Internet and American life project. Retrieved August $11^{\text {th }}$, 2015 from http://www.pewinternet.org/pdfs/PIP_Schools_Report.pdf

Levy, S. (2003). Six factors to consider when planning online distance learning programs in higher education. Online Journal of Distance Learning Administration, 6(1). Retrieved October $2^{\text {nd }} \quad, \quad 2015$, from http://www.westga.edu/ distance/ojdla/spring61/levy61.htm.

Marquie, J., Thon, B., \& Baracat, B.(1994). Age influence on attitudes of office workers faced with new computerized technology. Applied Ergonomics, 25, 130-142.

Matusevich, M. (1995, May). School reform: What role can technology play in a constructivist setting? Retrieved from http://delta.cs.vt.edu/edu/fis/techcons.html

Mishra, P., \& Koehler, M. J. (2006). Technological pedagogical content knowledge: A framework for teacher knowledge. Teachers College Record, 108 (6), 10171054.

O'Quinn, L. \& Corry, M. (2002). Factors that deter faculty from participating in distance education. Online Journal of Distance Learning Administration, 5(4). Retrieved September $\quad 2^{\text {nd }} \quad, \quad 2014, \quad$ from http://www.westga.edu/\%7Edistance/ojdla/winter54/winter54.htm

Obler, S., \& Schiorring, E. (2002). Ethnographic study: Technology training project study. Retrieved from ERIC.

Oppenheimer, T. (1999). The computer delusion. In D.fallon (Ed.), Technology and society: Perspectives (pp.69-81). Madison, WI: Course wise.

Panda, S. \& Mishra, S (2007). E-Learning in a mega open university: Faculty attitude, barriers and motivators. Educational Media International, 44(4), 323338

Poole, M., \& Jackson, M. (1993). Communication Theory and Group Support Systems. New Perspectives, 281-293.

Potosky, D., \& Bobko, P. (1998). The computer understanding and experience scale: A self-report measure of computer experience. Computers in Human Behavior, 14(2), 337-348.

Prensky, M. (2001, October). Digital natives, digital immigrants. On the Horizon, 9 (5), 1-6. doi:10.1108/10748120110424816

Rogers, P. L. (2000). Barriers to adopting emerging technologies in education. Journal of Educational Computing Research, 22(4), 455-472.

Schacter, J. (1999). The impact of education technology on student achievement: What the most current research has to say. Retrieved June $3^{\text {rd }}, 2014$ from http://www.mff.org/pbs/ME 161.pdf

Sigurdsson.J. (1991). Computer experience, attitudes toward computers and personality characteristics in psychology undergraduates. Personality and individual Differences, 12, 617-624. 
Soine, R. M. (1996). Require students to gain computer skills - now what? Teaching for Success, 8(2), 7.

Thang, SM., et al. (2016). ICT Tools Patterns of Use among Malaysian ESL Undergraduates. GEMA Online ${ }^{\circledR}$ Journal of Language Studies, 16(1), 2016

Taylor, S., \& Todd, P. (1995). Assessing IT usage: The role of prior experience. MIS Quarterly, 19(4), 561-570.

Thompson, R., Compeau, D., \& Higgins, C. (2006). Intentions to use information technologies: An integrative model. Journal of Organizational and End User Computing, 18(3), 25-47.

Vakalis, M.P. (1991). Attitudes of faculty towards computing: an investigation and analysis of related variables. In Proceedings of the 19th Annual Conference on Computer Science ( San Antonio, Texas, United States). CSC'91.ACM Press, New York, NY, 694. DOI=http://doi.acm.org/10.1145/327164.328861

Valentine. D. (2002). Distance learning: Promises, problems, and possibilities. The Online Journal of Distance Learning Administration, 5 (3). Retrieved October $15^{\text {th }} \quad, \quad 2014$, from http://www.westga.edu/ distance/ojdla/fall53/valentine53.html.

Venkatesh, V., Morris, M. G., Davis, G. B., \& Davis, F. D. (2003). User acceptance of information technology: Toward a unified view. MIS Quarterly, 27(3), 425478.

Waxman, H., Connell, M., \& Gray, J. (2002, December). A quantitative synthesis of recent research. Retrieved December 23 ${ }^{\text {rd }} 2014$ from http://www.coe.ufl.edu/Courses/eme5054/Foundations/ Articles/waxman.pdf

Woodrow, J. E. (1992), The influence of programming training on the computer literacy and attitudes of pre-service teachers. Journal of Research on Computing in Education, 25(2), 200-218.

Woods, R., Baker, J. D., \& Hopper, D. (2004). Hybrid structures: Instructors use and perception of web-based courseware as a supplement to face-to-face instruction. The Internet and Higher Education, 7(4), 281-297.

Woods, R., Baker, J. D., \& Hopper, D. (2004). Hybrid structures: Instructors use and perception of web-based courseware as a supplement to face-to-face instruction. The Internet and Higher Education, 7(4), 281-297.

Wozney, L., Venkatesh, V., \& Abrami, P. C. (2006). Implementing computer technologies: Teachers' perceptions and practices. Journal of Technology and Teacher Education, 14(1), 173-207.

Yang, H. H., Mohamed, D. A., \& Beyerbach, B. A. (1999). An investigation of computer anxiety among vocational-technical teachers. Journal of Industrial Teacher Education, 37(1), 64-82.

Yildirim, S. ( 2000). Effects of an educational computing course on pre-service and in-service teachers: A discussion and analysis of attitudes and use. Journal of Research on Computing in Education, 32, 479-495.

Yildirim, S. ( 2000). Effects of an educational computing course on pre-service and in-service teachers: A discussion and analysis of attitudes and use. Journal of Research on Computing in Education, 32, 479-495. 


\section{About the authors:}

Az-eddine KHALOUFI is a professor of linguistics and translation at the Faculty of Arts and Humanities, Moulay Ismail University, Meknés, Morocco. He published a number of articles within the field of linguistics. Translation, linguistics, and applied linguistics are his major research areas.

Hicham LAABIDI is a teacher-trainer at CREMF, Meknés, Morocco. He is also a part-time professor at the Faculty of Arts and Humanities, Moulay Ismail University, Meknés, Morocco. Besides, he is a $\mathrm{PhD}$ candidate in Discourse Creativity \& Society at Faculty of Arts and Humanities, Sais-Fes, Sidi Mohamed Ben Abdellah University, Fes, Morocco. 